\title{
Environmental situation of Baikal Lake
}

\author{
Varvara Shmalko ${ }^{1 *}$ and Elena Gogina ${ }^{1}$ \\ ${ }^{1}$ Moscow State University of Civil Engineering (MSUCE), Yaroslavskoye shosse, 26, Moscow, Russia, \\ 129337
}

\begin{abstract}
This article considers the ecological situation, which has developed around a unique natural object - Lake Baikal. There are studied physical and geographical characteristics of this lake, because it is one of the greatest lakes in the world and the largest freshwater lake in Russia. Lake Baikal is 1.7 times larger the Lake Ladoga, the largest lake in Europe. Baikal is the largest fresh water lake in the world. Its volume is 23600 cubic kilometers, which is about $20 \%$ of the planets' fresh lake water - much more than in all the freshwater lakes of the world. There are described the most large-scale tributaries, which fill the lake, as well as the only river, flowing from it. There are studied basin areas of this valuable lake, which are under protection. There are four main periods identified by analyzing the dynamics of wastewater performances.
\end{abstract}

Keywords: Baikal, ecology, basin, water supply

\section{Introduction}

Lake Baikal (fig.1) and its catchment basin belong to the unique geological systems of the world. Baikal is located in the central part of Eastern Siberia, near the conventional geographic center of Asia. The mountain hollow of the lake represents the most important natural boundary of Siberia. The borders of various floristic and faunal areas converge in this region, creating biogeocenoses that have no analogues.

Baikal is one of the greatest lakes of our planet: the deepest (1637 meters) and the oldest (about 25 million years old), containing the largest number of endemics (more than 1,000 species) and representatives of flora and fauna (more than 2600 species), inhabiting the fresh water bodies of the Earth. The lake has a unique reserve of fresh water (23 615 cubic kilometers) and quality ( $20 \%$ of world reserves).

The antiquity of Baikal is the most remarkable feature. Taking into consideration deep relict endemism of the lake fauna, the huge amount of researchers determine its age in 20-30 million years. The vast majority of lakes, especially the lakes with glacial and bayou origin, live 10-15 thousand years, then they are filled with sediments, dragged out by fusions, and sooner or later they turn into swamps and then dry up. Investigations of recent years have allowed geophysicists to put forward a hypothesis that Baikal, on the contrary, is a nascent ocean. This hypothesis is confirmed by the fact that its shores diverge at a speed of up to 2 $\mathrm{cm}$ per year, just as the continents of Africa and South America, the shores of the Mediterranean and Red Seas, etc. In the Baikal region, significant magnetic anomalies along its axis were noted, alongside with the active movements of the earths crust. On a scale, these

\footnotetext{
*Corresponding author: goginaes@mgsu.ru
} 
anomalies are comparable with similar anomalies in the area of the mid-Atlantic fault. The lake has many features inherent to the ocean - abyssal depths, huge mass of water, internal waves and seiches, tides, strong storms, high waves, expansion of the basin due to the expansion of the shores, large values of magnetic anomalies, etc.

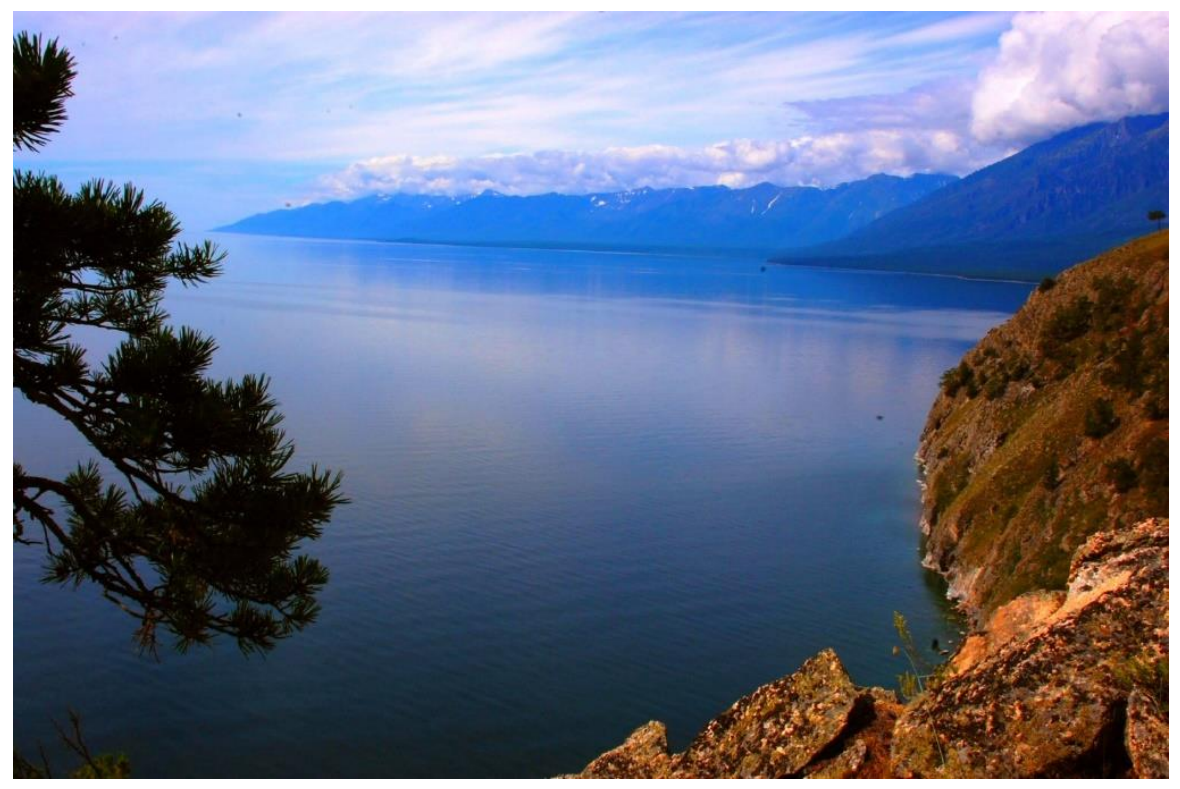

Fig. 1. Baikal Lake

The lake lies in the Baikal basin - a bottomless stone bowl, surrounded on all sides by mountains. The mid-altitude mountain ridges on the western side - Primorsky and Baikal, from the east and southeast - Barguzinsky (with a maximum height of $2840 \mathrm{~m}$.) and KhamarDaban, frame the cavity. The height of the mountains above it, the depth of the lake and the thickness of the loose sediments lining its bottom determine the depth of the depression. The layer of these lake sediments in some places reaches 6000 meters, and their volume is twice the volume of the lake and reaches 46,000 cubic kilometers. It is not difficult to calculate that the depth of the crystalline bed of Lake Baikal reaches 8 to 9 kilometers.

The basin of Baikal is the central link of the Baikal rift zone, which arose and develops simultaneously with the world rift system [1-3].

The deepest point of Baikal's basal bath lies about 7000 meters below the ocean level. The Baikal basin is the deepest basin on earth. Its "roots" dissect the entire earth's crust and go into the upper mantle to a depth of 50-60 kilometers.

Annually about 60 cubic kilometers of beautiful and unique water are reproduced in Baikal, which in some cases can be used instead of distilled. The rare purity of water is provided by the vital activity of its unique flora and fauna. The main properties of Baikal water are characterized as follows: there are very few dissolved and suspended mineral substances, negligible organic impurities, and a lot of oxygen. The total mineralization of water in Lake Baikal is 120 milligrams per liter, while in many other lakes it reaches 400 or more milligrams per liter. The total content of ions in the lake water is 96.7 milligrams per liter.

Transparency depends from the purity of water. Baikal not only extremely clean, but also is the most transparent lake in the world. Baikal water transparency reaches 40 meters (tens of times more than in many other lakes), it happens in spring, after breaking of the ice. The water of the Sargasso Sea is a gold standard of the highest transparency, which is approaching 
the transparency of distilled water. Here the disc of Secchi disappears from sight at a record depth of 65 meters. Recent investigations have shown that at depths from 250 to 1200 meters the transparency of Baikal water is not less than in the Sargasso Sea.

The catchment basin of Lake Baikal covers an area of 541 thousand square kilometers (without the area of the Baikal water area - 31.5 thousand square kilometers). There are 240500 square kilometers of the basin of surface and underground runoff into Baikal is located on the territory of Russia. The rest of the catchment basin (300.5 thousand square kilometers) is within Mongolia [13].

The entire lake basin is a peculiar and very fragile natural geosystem, the basis of which is the lake system with its natural formation process of the purest waters of drinking quality $[1,4]$.

\section{The water basin of Lake Baikal}

Baikal collects water from a vast territory - rivers flow into it, starting far in the mountains of northern latitudes, and on the plains of the south. More than 300 rivers flow into the lake. The exact number is unknown, since in dry years the number of rivers decreases, and in rainy - accordingly increases. Among them, there are large navigable and floating rivers, which spread far, mainly to taiga areas, but there are also small ones that can be crossed.

The largest of the rivers flowing into Baikal is the deep-water Selenga, which is the main artery of the southeastern part of Transbaikalia. The origins of the Selenga River are in the steppe expanses of the Mongolian People's Republic. Passing the state border, the river flows at a distance of $415 \mathrm{~km}$ along the territory of the Buryat-Mongolian ASSR and flows into Baikal. It is navigable on a large extent; large tributaries - Hilok and Chikoy - are navigable too.

There is one astonishing feature peculiar to Selenge. The water in Selenga all year round and especially in summer is cloudy, unlike the other rivers flowing into the lake, where the water is usually clean and transparent. This is explained by the fact that in its origins - in the steppes of Mongolia - the climate is sharply continental, almost no vegetation and all year round strong winds are blowing. Winds pick up small grains of sand, grind them into the finest powder and spread them to large spaces. Rainwater captures fine dust and demolishes into the rivers - the tributaries of Selenga.

Despite the relatively slow Selenga current, fine dust particles do not settle to the bottom and the flow of water carries them to Baikal. Selenga's turbidity is also explained by the fact that the river flows through the territory where loesslike loams are widespread. A number of small mountain rivers flow into Selenga in addition to the steppe tributaries; their violent flows produce a great destructive work and carry huge masses of sand and larger particles. One part of this material is deposited in the channel of the Selenga, and the other is carried to the lake, where the particles are first dispersed by waves, and then gradually fall to the bottom, forming a wide shallow water near the river delta. So the muddy waters of the Selenga River carry a huge amount of suspended, small particles to Lake Baikal, which are deposited in the lake as in a gigantic settler. Because of this process, which lasts for millennia, Baikal had to retreat in the region of the confluence of the river far to the west. On the site of the vast bay of the lake, due to the material brought in, formed an even, vast inland area of the delta; At present, wide tracts of mowing, fields, several dozen settlements are spread over it. Not every inhabitant of the villages will believe that once in the distant past the waves raged at the place where his house stands.

The next largest tributary of the Baikal - the Barguzin River - has a length of about 400 $\mathrm{km}$. In the upper reaches, it is as calm as all the rivers of the plains. Twisting, breaking into many channels, the river slowly flows along the wide flat-bottomed Barguzin depression to the mountain lintel, which separates the depression from the lake. Having reached it, the 
waters of the river, quickly gaining speed, rush towards Baikal. In the lower reaches of the river it is already like a mountain river - fast, dotted with rushes.

From the north, another large river - the Upper Angara - falls into Baikal. It is less abundant than Selenga and Barguzin, its length is $439 \mathrm{~km}$. The river flows through two large basins, framed by mountain ranges from the west to the east.

Other rivers flowing into the Baikal are less abundant and less noticeable. The largest of them - Kichera, Turka, Snezhnaya, Goloustnaya - are less than $170 \mathrm{~km}$ lengthwise. The remaining rivers are small, shallow, but fast and turbulent. They start from the slopes of ridges, a dense ring surrounding the lake $[2,7,8]$.

In 2014, the annual flow to Baikal was below the average long-term values of 41.9 cubic kilometers ( 1.33 thousand $\mathrm{m}^{3} / \mathrm{s}$ cubic metres per second), which is $21 \%$ less than in 2013 , when the runoff was 52.98 cubic kilometers $\left(1.67\right.$ thousand $\left.\mathrm{m}^{3} / \mathrm{s}\right)[9,10,13]$.

Many rivers carry their waters into Baikal; the only river that flows out of it is the Angara [2]. The river results in the source the formation of river flow in the Baikal watershed and the processes of its purification by the ecosystem of Lake Baikal. The average annual volume of annual runoff from the lake is 60 cubic kilometers, which corresponds to a water discharge of 1.9 thousand $\mathrm{m}^{3} / \mathrm{s}$ [13].

The length of this "daughter of Baikal" is about $1860 \mathrm{~km}$. Every year, Angara takes out 60.9 cubic kilometers of water from Lake Baikal, and all its tributaries bring 58.75 cubic kilometers per year. It is noteworthy that the Angara at the mouth, at the confluence of the Yenisei, brings 120 cubic kilometers of water in a year, and the Yenisei in front of the confluence of the Angara has a water discharge of only about 100 cubic kilometers. The source of the river is located at the level of Baikal, i.e. at an altitude of $456 \mathrm{~m}$ above the level of the world ocean, and the mouth - at a height of $76 \mathrm{~m}$. The difference is $380 \mathrm{~m}$, which is used by a cascade of hydroelectric power stations built on the Angara. The width of the Angara in the source is about $1 \mathrm{~km}$, the depth varies from 0.5 to $6 \mathrm{~m}$, the flow velocity along the channel is $1-2 \mathrm{~m} / \mathrm{sec}[2]$.

\section{Protected natural territories in the basin of Lake Baikal}

In the Baikal region, there is a network of specially protected areas. Within the boundaries of the Baikal Natural Territory (BNT), 5 preserves, 3 national parks, 23 reserves, 128 nature monuments, 1 botanical garden, medical and health areas and resorts represent the network of specially protected natural areas (SPA). The Botanical Garden with an area of 27.1 hectares is located in Irkutsk and is managed by the Irkutsk State University. Within the boundaries of the BPT, there are five recreational areas - «Baikal Priboy-Kultushnaya» and «Lemasovo» in the Kabansky District, «North Baikal» in the Severobaikalsk District, «Barguzinsky Coast of Baikal» in Barguzinsky District and «Lake Shchuchye» in Selenginskoye District. These recreational areas are located in the Republic of Buryatia and are managed by the administration of municipalities [11,12].

The SPA area within the BPT is 39.7 thousand square kilometers, which is $10 \%$ of the BPT area. Within the boundaries of the CES of the BTT and the site of the World Natural Heritage «Lake Baikal», the SPA occupy 25.6 thousand square kilometers ( $29 \%$ of the CES area).

\section{Sewage waters and polluting surface substances}

Analysis of wastewater performance dynamics in the Irkutsk region for 1981-2003 years identified four main periods. In the first period (1981-1987), there was a relative stability of wastewater volumes, including polluted runoff. 
In the second period (1988-1989), there was a rapid increase in the volume of polluted runoff, with a slight increase in the volume of sewage, which is due to a certain objectivization of statistical reporting, primarily the registration of enterprises of the militaryindustrial complex and the well-founded trans-over of a significant part of normatively clean and normatively cleaned wastewater into the category of contaminated.

A hallmark of the third period (1990-1998) is the reduction of wastewater, including polluted runoff, caused by a general decline of industrial production in the region.

The fourth period (1999-2003) is characterized by the stabilization of the wastewater indicators at the lowest level in recent decades. Indicators of the volumes of wastewater discharged into water bodies (2.21 cubic kilometers), including polluted runoff (1.92 cubic kilometers) fixed in 1990, decreased 1.8 and 2.3 times respectively by the year $2003[5,6]$.

\section{Conclusions}

The Lake Baikal has a unique hydrological and chemical regime. The uniqueness of the hydrological regime lies in the fact that water exchange occurs throughout the water column. The lake is surrounded by mountain-taiga landscapes and specially protected natural areas, mostly preserved in the natural state and representing additional value.

In an effort to preserve original form of this natural object and not to damage the exceptional endemic fauna and flora, it is necessary to investigate deeper both the Baikal waters and the surrounding territories.

It is necessary to increase the number of observation posts, coordinate work on exploring, reproducing, using and protecting the natural resources of the Baikal natural territory, preserving biological diversity, ensuring environmental safety, and solving the region's social and economic objectives on the principles of sustainable development.

The Lake Baikal is a cosmoplanetary phenomenon, the real natural monument, which has outstanding value from science and aesthetics point of view. The beauty of Baikal is an irreplaceable and unrenewable wealth. Sooner or later progress of science and technology will help to find a substitute for raw materials, but nothing will help us to reproduce the aesthetic appeal of Lake Baikal.

\section{References}

1. http://www.obaykale.ru/baykal-obshie-dannye_04.htm

2. S.G. Sargsyan, Gos. publishing of geographical literature (1955)

3. Present and future of the Baikal region (opportunities for sustainable development) (1996)

4. Ryashchenko S.V., Savenkova T.P., Snytko V.A., Geogr. and natur. Resources 3, 4449 (1998)

5. Znamensky V.A., Wat. Res., 3. 76, (1975)

6. Natural resources and environmental protection / Statistical compilation (2004)

7. Bezrukov L.A., Misyurkev Yu.A. - Geographical and cartographic assessment of the use, pollution and protection of the Irkutsk region waters // Geogr. and nat. res., 2 (1995)

8. N. Makisha, Pr. Eng., 165, 1087-1092 (2016)

9. N. Makisha, I. Panteleeva, MATEC Web of Conferences, 106, 70015 (2017)

10. http://baikalarea.ru/pribaikal/villages/baikalsk/a8793.htm

11. Certificate of the results of inspection of facilities and equipment of JSC «BPPM» from May 6, 2014.

12. https://03grb.ru/news/43403 
13. http://ekogradmoscow.ru/novosti/pochemu-net-ochistnykh-sooruzhenij-nabajkale

14. Garmaeva E.P., Dambayev T.S., Sheluheev A.A., General plan of the «Tanghoi» Kabansky District of the Republic of Buryatia - Explanatory note - 3406 - pz.

15. N. Makisha, E3S Web of Conferences, 6, 01002 (2016) 